\title{
Visible Religion and Populism: An Explosive Cocktail
}

\author{
Walter Lesch
}

Institut de Recherche "Religions, Spiritualités, Cultures, Sociétés" (RSCS), Université catholique de Louvain, Grand-Place 45, bte L3.01.01, 1348 Louvain-la-Neuve, Belgium; walter.lesch@uclouvain.be

Received: 14 July 2020; Accepted: 3 August 2020; Published: 5 August 2020

\begin{abstract}
Populism frequently uses the visibility of religious majorities and minorities as polemically charged references in the political controversy about cultural identity. Visible signs are evoked as positive identity markers and representations of the fiction of a homogenous society. The visibility of religions coming from an immigration background is more likely to be attacked as an invasion of foreigners who do not fit in the frame of an imagined authentic model of cultural unity. As the debates on the construction of mosques and minarets in European cities show, Islam becomes a synonym of differences perceived as problematic. Depending on the political agenda, invisible and quiet religions are preferred to the visible and politically more demanding ones. However, the opinions for or against a high degree of visibility are not necessarily shared within the religious communities. Their members can ask for discrete individual practices or for a strong collective presence in the public sphere. Populist discourses try to argue against manifestations of ostentatious visibility and use this fight as a platform for identity-driven propaganda that is interested in the exclusion of those who are considered as the threat to the well-being of the "people". The visibility of religion thesis has to be dealt with carefully in the context of right-wing populism because of the toxic effects of all kinds of identity politics in the political as well as in the religious sphere. The conventional implications of the public-private split must be rearticulated in a context in which secularism is challenged by the return of visible religion and by the emergence of political ideologies playing with the fire of strong and exclusivist identity claims that are in conflict with ideals of tolerance, pluralism, and diversity management.
\end{abstract}

Keywords: fear; Islamophobia; pluralism; populism; public religion; racism; tolerance; visible religion

\section{Introduction}

This essay explores some connecting lines between two phenomena that are already not easy to describe independently from each other, so it might be even more problematic to bring them together without having a robust working hypothesis for the start of the investigation. Populist movements are visible in the public sphere of most liberal democracies and have become a subject of strong normative views on the dangers or the desirability of a profound transformation of the balance of power between traditional political parties (Urbinati 2013; Bonikowski 2016). From a skeptical point of view, populism is seen as an over-simplistic and demagogical threat to a rational culture of deliberation and decision-making. From a less alarmist perspective, populists are considered as an integral part of the legitimate range of options and tend to contribute to a revitalization of political discourses that had lost their dynamics due to numerous rules of political correctness. Populism as a fundamental critique of mainstream ideologies can exist in progressive, conservative, and openly right-wing and nationalist expressions (Mudde and Rovira Kaltwasser 2017). What has been discussed during the last years as the populist challenge within liberal societies is mostly associated with the illiberal extreme-right protest against immigration, multicultural citizenship, LGBTQ rights, and many other characteristics of an open society. 
It is taken for granted that the actors in the political arena have to be visible and that they usually do all they can in order to promote a high level of visibility in the media society. There is certainly an impressive variety of historically grown conditions within Europe. One common reference point for most European countries is the rise of the extreme right in the course of the so-called refugee crisis in 2015. The new experience with right-wing populists is that they mistrust the media as totally supervised by what they call the establishment. Open-minded citizens who stand up for the freedom of expression are less convinced of the effects of their tolerant spirit when it comes to giving a platform to potential enemies of democracy and pluralism. The fierce fight for visibility is inevitably a feature of most controversies on populism and underlines the importance of controlling the channels of communication. This is even more complex in the age of social media than under the circumstances of conventional journalism. The idealized public sphere is far from being without power relations. Its configuration depends on a legal framework, regulations of access, professional norms, and the attitudes of the public that wants certain ideas to become audible and visible. In other words, visibility is not only a major topic in recent religious studies (Ward and Hoelzl 2008; Hjelm 2015); it is also relevant in political science and its particular sensitivity to the effects of the attention economy.

As it is important to be heard and seen in the public debate, the requirement of visibility and attention becomes a decisive instrument of influence. The other side of the coin is the temptation to exclude competitors who are not less interested in being listened to and being seen. The aspect to be more specifically discussed in this article is the rivalry between political and religious claims with respect to value judgements on populist ideologies (Lesch 2017). Even if populist parties do not necessarily have a clearly constructed agenda dealing with religious issues, they are confronted with messages coming from churches and other communities. When religious people, theologians, and experts in religious studies reject any instrumentalization of religion for political purposes, populists can no longer use the vague reference to a religion as an affirmation of a programmatic discrimination of those who do not fit in the ideological frame of a worldview that has been constructed with a logic of exclusion. According to a nationalist perspective, the feeling of belonging to a particular people implies a common history, common cultural roots, and maybe religious beliefs. Some members of right-wing parties are deeply convinced that there is no contradiction between their political home and their Christian faith (Althoff 2018). Such an approach becomes problematic when it is used to fuel the simple narrative of "us" against "them" by insisting on religious differences.

In the context of the discussion about the visibility of religion thesis as a heuristic key to contemporary society, the constellation of religions and populism (Zúquete 2017; DeHanas and Shterin 2019) represents an exciting test case. When religions are categorically banned from the public sphere and limited to private expressions of personal beliefs, they cannot really disturb the other competitors in the struggle for visibility. As soon as religions are considered as partners in societal dialogues, religious language, traditions, rituals, and symbols become part of the cultural input and have to be taken seriously (Mendieta and VanAntwerpen 2011; Könemann and Wendel 2016). The populist imagination of a "Christian Occident" often uses Christian symbols as identity markers, for example the cross. It also uses symbols supposed to represent Islam as a religion in conflict with this imagined Christian well-ordered tradition. Populist polemics are to a great extent about the irritating expressions of visible religions: those belonging to the majority and those coming from minorities and immigrant cultures. When populist politicians praise the superiority of a homogenous cultural identity, they do so in contrast with the image of foreign influences, which are presented as risks for cohesion and peaceful coexistence. Whereas the abstract links between religion and populism can have many different dimensions and historical ramifications, the combination becomes an explosive cocktail in the rivalry for visibility in party conventions, election campaigns, protest marches, and other demonstrations with a high media exposure. This is why the visibility of religion thesis is a promising tool in the research on the connections between religion and populism. It helps to draw attention to the procedures of giving access to visibility in a context that is so strongly dominated by visual culture. It is recommendable to focus on the mechanisms at work in the configuration of the 
field of view, which is rarely an objective illustration of all those who wish to be present in the public sphere by their active participation or by chosen representatives.

The clash of populism and religion cannot leave any citizen indifferent as soon as the fundamental principles of the communication between free and equal persons are at stake. When populists claim to speak in the name of the "people" that is no longer heard and seen because of the blind spots and deliberately hostile strategies of the so-called mainstream media, they themselves play the deplored tactical game: the exclusion of those they want to be defined as foreigners and enemies of the people. The enemy stereotypes can be adapted to various groups of outsiders; the strategy is always the same: making the "foreign" visible so that it can be selected as an easy target and efficiently fought against. The defamatory play with a real or imagined visibility has no other aim than the elimination of the visible strangers who do not deserve the people's solidarity according to a self-proclaimed popular voice. It is especially perfidious to exploit the visibility of identity markers for the stigmatization of targeted groups and individuals who are often already in a marginalized and precarious position.

We can try to test the visibility of religion thesis with the help of a simple thought experiment. Let us imagine a society in which religions considered as problematic by the majority do not disturb if they stick to a low profile and remain practically invisible. They are accepted as personal beliefs and discreetly practiced rituals as far as they do not ask for a publicly visible, prestigious, or even publicly financed place of worship. They hide away as if they were ashamed to show a practice that could be seen as an indecent exposure. This is the way people behave in tyrannies and totalitarian regimes where the permanent intimidation by a state of fear makes any benevolence and recognition impossible. The violent suppression of free expression transforms self-confident individuals into anxious persons who do no longer dare to share their deepest convictions because they could be regarded as politically unwelcome. As a counterproposal to insecurity and persecution, liberal democracies are based on a social contract that stipulates equal rights and opportunities regardless of religious beliefs and practices and opens the public sphere to the free flow of ideas as long as these ideas are not intended to put an end to the freedom.

The populist reference to religion, particularly to its visible dimension, is ambiguous. On the one hand, religious symbolism is sometimes used as an integral part of the ideologically acclaimed majority culture and serves as a strong mark of popular identity. On the other hand, religion is criticized whenever it does not fit in the framework of autochthonous traditions, because it comes from foreign cultural backgrounds, or when it takes a critical stance on the populist ideology's intolerant effects. When religions transcend the sphere of private practice and become political, they disturb the tacit arrangement of the public-private split and get into the focus of power conflicts. This is exactly what happens when populists deal with visible religion as a potential ally or as an enemy. In both cases, religions are projection screens of identity discourses and find themselves involuntarily on the rough ground of disputed claims. What is at stake is nothing less than the question of deciding who should be allowed to openly express a way of life that could serve as a role model for a collective identity. All those who are not recognized as publicly acceptable lifestyles should better hide away and avoid any confrontation with the strong popular forces in power.

Populists hate diversity and what they denounce as left-wing identity politics. They try to make people invisible and to silence them because they are different from an imagined embodiment of the people's ideal manifestation in an ethnonationalist homogeneity. When populists are under pressure because of these ostracizing policies incompatible with human rights, they defend themselves by playing the victim role. They complain about being treated badly by the media and about being excluded from discussions in which they would like to present their legitimate points of view. Populism belongs to the controversies in a robust democracy as long as fundamental rules of transparency and free speech are respected. It would turn out to be counterproductive to systematically silence populist ambitions, because such a strategy might be used as a confirmation of the allegation that corrupt and power-hungry elites want to dominate the silent and invisible majority of honorable citizens. 
The visibility thesis has the advantage of being a tool in the religious as well as in the political field. It makes us think about the mechanisms of power and the authorities that are in a legitimate position to regulate the access to visibility and audibility. During the last decades, societies of the Western world have massively broadened the spectrum of visible and audible expressions of different ideas, beliefs, and lifestyles. National populism can partly be interpreted as a backlash against the aspirations of multiculturalism and cosmopolitanism that could not keep the promise of a better world. We are in the middle of this process as observers, participants, and agents and search for understanding and normative orientation. The study of populist movements helps to reveal the underestimated influence of the longing for collective identity and the fragility of peaceful multicultural coexistence. The study of religions helps to explore the interaction between the intimacy of religious beliefs and the public commitment. The combination of the political and the religious question is expected to make a contribution to political theory and to the study of religion as two relevant and sometimes intertwined factors even in secularized societies.

\section{Some Cases}

After the introductory considerations, two more specific topics are now presented as illustrations of the theoretical framework. They are different and yet complementary because they show the contradictions of Western societies from the perspective of an ongoing debate on the future of religious and cultural diversity. The first set of cases refers to the well-known controversies about the visibility of Islam and the integration of Muslim citizens in Europe. The second series of observations goes back to a non-European context: the intellectual and political framing of multiculturalism in the Canadian province of Quebec, where several attempts have been made to create a credible and feasible alternative to the French model of "laïcité" and its implementation of secularism. While the first context illustrates attitudes of rejection, the second one puts forward scenarios of coexistence and inclusion. These exemplary narratives do not pretend to represent the broad spectrum of historically and empirically documented cases. They have been chosen as models of typical controversies over the organization of the public sphere having to deal with manifestations of visible religion.

\subsection{Mosques and Minarets}

If there were only one case that should be chosen to highlight the European problem with a visible presence of Islam, it could be the Swiss popular vote from 2009, when a majority expressed the political wish to ban minarets from a traditional landscape and urban skyline that is used to churches, church towers, and the ringing of bells and not to mosques, minarets, and the muezzin's call to prayer. What appears as an absurd exaggeration of xenophobia and nostalgic celebration of traditional values was able to organize a majority of Swiss citizens who found themselves under pressure from the exotic symbols of a religion brought to Switzerland by immigrants who want to be accepted as full members of their new home country after decades of marginalization, discrimination, and struggle for integration. The possibility of having appropriate places of worship is an integral part of a recognition that would be less convincing if mosques still had to be constructed outside the city centers, far from wealthy residential neighborhoods, often in commercial areas on the outskirts, and without any architectural or aesthetic ambition. Such buildings were made to be insignificant and almost invisible at the scale of the urban community.

The sociologist Nilüfer Göle has written a very instructive paper on the minarets-mosques debate, with special attention paid to the aspect of public visibility (Göle 2011). She mentions an insightful episode in Recep Tayyip Ergoğan's rise to power. The current president of Turkey was condemned to ten months of prison in 1998 for having quoted a poem in which "minarets were compared to bayonets, mosques to barracks, and Muslims to soldiers" (Göle 2011, p. 385). He did so in 1997 when he was already the very popular ruling mayor of Istanbul and participated in a campaign rally in Eastern Turkey. The aggressive rhetoric surprises in the context of a country that is known for the architectural visibility of mosques. But the secular forces of the Turkish Republic suspected Erdoğan of his long-term 
agenda of an Islamization of the state. The verses taken from a poem written by a nationalist activist were considered as an incitement to violence and hatred and had to be banned from public discourse based on secular values. The incident is more than anecdotal because it demonstrates a line of conflict that is still present in the debates on the visual symbols of religious power. No wonder that the poem's verses reappeared in the Swiss minaret debate and in similar disputes.

As the Erdoğan case shows, and as Göle puts it, the "lost innocence of mosques" has been largely exploited by all kinds of populist movements with an Islamophobic strategy. It is an irony of history that the Turkish authorities in 1998 did not take the military metaphors for granted, even in a country that is marked by the architecture of mosques in all cities and villages. The constructions as such have nothing that could justify the verdict of an endangerment of public order and peaceful coexistence. The perception of a potential danger is a matter of interpretation and happens in the eyes of the observer who is influenced or not by the hostile implications of an identity statement.

The Swiss popular initiative "against the construction of minarets" is an example par excellence of an intoxicated communication in a country where only very few minarets can be found. The minarets became a symbol of a growing Islamization and had to be made visible in the excessive iconography of the poster campaign. The political forces behind the referendum succeeded in presenting the minarets as a convincing pars pro toto, implying further elements that fuel the fear of Islam: headscarves and other vestimentary statements, as well as the whole set of rules concerning nutrition and food production. As minarets were not massively visible in Switzerland, the political groups that orchestrated the campaign had to create the impression of an overwhelming menace with the dimensions of a hostile invasion (Gonzalez 2015). The result of the referendum in 2009 was unexpected because the critical voices from all parts of the civil society and from the political institutions had been quite clear with their negative view on the initiative. The success inspired many populists in other countries where the blueprint of the counterfactual assertation of a high visibility of Islam could be used to stimulate fear among potential supporters of right-wing propaganda.

The Swiss case is just one example among many others going in the same direction of a problematization of the Muslim community's visibility presented as a threat to an open society. The resentment is finally about the old challenge of transforming immigrants to full members of a welcoming society (Jonker and Amiraux 2006; Doganyilmaz Duman 2018). This demands adaptations and compromises from both sides. Foreigners cannot seriously be expected to deny their roots, and the majority society cannot continue defending relentlessly an unchangeable and sacrosanct way of life. Foreigners have to become visible in order to participate in relevant decisions. Visibility, as Göle puts it with Hannah Arendt, is a necessary condition of political agency. "To appear always means to seem to others. It is perceived by a plurality of spectators; therefore, a public is by definition pluralistic. And therefore, citizenship is not prior to public appearance, but one becomes a citizen as one makes oneself visible to others" (Göle 2011, p. 390). The wish to make people invisible does not solve any problem and only intensifies the conflict in a more radical struggle for recognition. It remains controversial whether minarets or church towers have anything to do with the status of full citizens. But this fundamental question should not be used as a hypocritical attempt to get rid of the difficulty. Church-state relations are shaped by a legal framework of regulations. It is a matter of fairness to see the same compelling necessity for the clarification of the status of other religious communities. If this were not the case, it would be a cowardly approval of the populist agenda directed explicitly against Islam.

\subsection{Reasonable Accommodations}

The European debates on mosques and minarets represent the case of a politics of fear grounded in a rejection mentality when it comes to a long-term interpretation of immigration and integration (Carens 2013; Battistella 2017). The cultural background of migrants is seen as a threat to a majority culture that paradoxically rediscovers or reconstructs its own roots in spite of decades of dechristianization. The newcomers are expected to adapt their visible lifestyle as much as possible 
to the majority's manners and to avoid ostentatious manifestations of their differences. The approach is radically different in a society that understands itself as an immigration country depending on the valuable contributions coming from foreigners who accept the deal of a certain kind of integration without denying their identity. The Canadian province of Quebec is an interesting case of such an option for openness and plurality. Quebec's own identity marker is the French language as a distinctive feature in a country with an anglophone majority. Immigrants must be willing to speak French in order to preserve this peculiarity. But they are free to stick to their habits insofar as they are not in conflict with the constitutional foundation of a liberal state of law.

The case of Quebec has awakened an international interest because of the attempt to keep the balance between the respect of unavoidable common rules and the recognition of specific communities and their cultural and religious habits. Multiculturalism (some prefer the term interculturalism in order to underline that it is an interaction between and not a simple juxtaposition of cultures) was meant to be the promise of a tolerant and flexible society, open to strangers and inviting them to feel at home in the new environment. In the eyes of conservative politicians and voters, this went much too far and was seen as a lack of orientation within the French-Canadian population with regard to its history and its way of life. Finally, the ongoing controversies deal with the definition of the common ground that has to be shared by all citizens and residents. The fundamental importance of such a common reference point has always been largely accepted also by convinced multiculturalists (or interculturalists) who insist on the guiding principles of human rights. It is much more difficult to decide where we leave these shared principles and come to the slippery slope of particularism and communitarianism. From the human rights perspective, diversity in cultural, religious, and sexual orientation has to be respected in the name of individual freedom. The communitarian dimension of such choices seems to be a greater challenge, as it implies the public recognition of unfamiliar visible practices.

The practical model tested in Quebec is known as the option for so-called "reasonable accommodations" when minority groups ask for their specific rights to celebrate or pray in what is seen as a neutral space. Whenever their demands are not a disproportionate burden, the rules can be modified and lead to a tolerant practice that is accepted as reasonable. It does not hurt anybody and helps to improve cohesion and peaceful coexistence. In other words, the basic framework remains the same with the obligation to guarantee the neutrality and impartiality of public services. It makes sense to welcome differences that are compatible with these general rules. In the context of anti-discrimination laws, the idea of reasonable accommodations comes from regulations in labor law where modifications of norms had been discussed, for example in order to make the integration of disabled persons easier. The context of religious minorities is more complicated because the definition of a specific accommodation in terms of burden or hurtfulness is far more controversial. Many Quebecois interculturalists would agree that it is not the same thing if headscarves or other distinctive signs are worn by employees of a public administration or by people at their place of work in a private company or simply in urban spaces open to everybody.

The experiences with accommodations were not unanimously welcomed in Quebec and triggered a new round of heated public discussions about the national identity. In order to calm these tensions, a commission was created in 2007, the Bouchard-Taylor Commission, under the chairmanship of the historian and sociologist Gérard Bouchard and the philosopher Charles Taylor who had to deliver their final report in 2008. This document (Bouchard and Taylor 2008) contains in a nutshell many of the typical elements that are to be considered when we want to understand the perception of visible religion. Taylor and Bouchard had made an impressive effort to study the real conflicts in the country and to have a maximum of empirical evidence for the practical recommendations formulated at the end of the report.

If the main purpose of the Bouchard-Taylor Commission was to calm the spirits in Quebec, this noble aim has obviously not been achieved. The Parti Québécois under Premier Pauline Marois tried to get a majority for the Quebec Charter of Values (Bill 60) as a clarification of the inarguably secular 
character of the province. Among the norms to be implemented, the text suggested the prohibition of religious symbols in the public sector where employees should not be allowed to have their faces covered (Assemblée nationale du Québec 2013). The Muslim community was once again the main target of potential political decisions. The initial project of the charter provoked an intense debate and divided the civil society in two camps of more or less the same size: those in favor of the consequences of radical "laïcité" and those who would have preferred the continuation of the intercultural vision of generously applied reasonable accommodations. This division shows to what extent the political consensus on issues of religious visibility is hard to reach by the means of rational argumentation. The initiative from 2013 has until now not led to any parliamentary consent. Even a traditionally migration-friendly society like Quebec is unable to agree on a strategy of inclusion and regularly gets back to the ideology of a national identity rooted in a Christian tradition or in secular values.

Both examples, the Swiss minaret debate and the controversial Canadian attempts to encourage religious diversity and inclusion, reveal the difficulties that self-declared pluralist societies still have to face when it comes to an official and unambiguous legitimation of the visibility of various religious traditions. What is accepted theoretically seems to be practically more challenging. But even the theoretical framing is not yet robust enough to support a culture of visual plurality and tolerance. The following sections summarize some efforts to understand the tensions between trends towards higher or lower degrees of visible religion and the consequences for the confrontation with xenophobic populism.

\section{Invisible Religion and the Private Sphere}

A religion is more easily appreciated or treated with indifference when it remains in the private sphere of individuals who are not interested in disturbing others with their personal beliefs and practical expressions of these convictions. Such a tactful practice of religion makes it more probable to feel safe in the privacy of a faith that will not be considered as a provocation in the eyes of those who prefer to keep public spaces free from religious aspects. The invisibility of religion is not necessarily a consequence of discrimination. The preference for a low profile practice can be the result of a deliberate opting for the inner values of a tradition that does not need a permanent public exhibition of its importance and seriousness. Spirituality and mystical experiences exist quite well without the showcase and the light of an institutional staging and magisterial supervision (Bochinger et al. 2009).

The more recent visibility thesis of religion cannot be understood without the background of its sociological counterpart: the emphasis on "invisible religion" (Luckmann 1967) as a relevant diagnosis of religiosity in an individualized context. Whereas visibility is associated with superficiality, herd instinct, social pressure, and in some cases even hypocrisy, the invisible practice allows the cultivation of a more reflected, critical, mystical, and individually appropriated form of spirituality and religion. The preference for "invisible religion" typically has its place either in situations in which religious freedom is threatened by illiberal regimes or under conditions of extremely liberal societies where the freedom of choice in religious matters is taken for granted. The impulse to switch from invisibility to more visibility depends not only on individual choices. It is also linked to the institutional arrangement in societal and political structures and in the religious tradition itself. A religion looking for public impact will always openly demand not to be limited in its private forms of expression (Casanova 1994). Luckmann's stimulating diagnosis going back to the late 1960s and a specific context of debates of secularism has to be reconsidered in a completely changed religious landscape (Knoblauch 2003) in order to avoid category mistakes.

The dichotomies of visibility and invisibility and of private and public (Beaman 2014) are still useful indicators of the way religious presence and diversity are perceived and evaluated by right-wing populists. The intellectual and spiritual strength of invisible religion becomes a weakness when political ideologies impose the rules of what should be seen and what should be expelled from the visible common ground of acceptable worldviews and expressions. The most invisible and private choices become political issues if those other than the persons directly concerned place the spotlight on these personal options and transform them into aspects of a clash between unreconcilable positions. 


\section{Degrees of Visibility: A Selective Perception}

The question is not so much whether to make general statements for religions to be invisible and silenced or to make them very visible and to give them a strong voice. These extremes are supposed to be excluded as undesirable options because nobody can honestly wish to live in a world in which existential and symbolic dimensions are systematically excluded from debates. The other extreme would be the domination of minds and souls by one religion looking for control and putting an end to plurality.

There are good arguments coming from the religious communities themselves that argue in favor of more visibility in the sense of more participation in debates and decision-making. Public presence is a powerful means to increase the vitality of a tradition. Without such a permanent challenge, religions can turn into introverted and pious exercises of self-sufficient rituals. As far as the public utility of religions has been recognized by public authorities, this is usually expressed by legal regulations, such as guarantees of religious freedom. In this perspective, visibility is just another word for participation, integration, and self-critical evolution. Christianity's encounter with Enlightenment is an example of such a historic chance of transformative learning and broadening of perspectives under the conditions of critical analysis and self-reflective participation in public discussion.

In societies historically characterized by a majority culture influenced by Christian traditions, the new element is the growing visibility of Islam and its demands for the public recognition of its visibility. Once again, the problem is not the visibility as such, but the identification of criteria that distinguish between appropriate and less appropriate manifestations of belief and belonging. Religious people are told that they are free to practice their faith, but they should avoid ostentatious signs and conspicuous symbols. These strong evaluations simply point to an excessive display of identity markers without being able to give clear criteria for a rational discernment. When do signs start to be considered as ostentatious, shocking, and dangerous? Who is entitled to decide about a ban of these signs that used to be part of the internal affairs of the religious community? Is it appropriate to have a look from outside at these so-called internal affairs if they are in clear contradiction to fundamental values, for instance the respect of women's rights?

Populists do not hesitate to use ostentatious signs of the majority religion (the cross at the far-right Pegida demonstrations in Dresden in 2014 and 2015) and are at the same time determined to polemicize against the public visibility of Muslim citizens whose specific rules for clothing, nutrition, and places of worship are seen as strange and troublesome. Similar observations can be made in different political contexts. It is revealing to see the use of religion in a very religious culture as in the USA (Wellman 2019) and in a secularist setting as in France (Scott 2007; Nilsson 2018). In both cases, religion offers a sounding board for populist attempts to "hijack" religion (Marzouki et al. 2016).

The struggle for or against the visibility of a certain tradition implies contradictions in the construction of a coherent approach. It is one thing to argue in favor of the visual presence of all persons in the public sphere without any discrimination because of religious, ethnic, or other aspects. On the other hand, the handling of visibility is contradictory in the tradition itself. The most prominent example of this part of the debate is the perception of the covered face in a democratic society. Does it make sense to ask for the highest visibility by sending the signal of not being completely visible in face-to-face communication? Populist movements successfully exploit this sensitive point by presenting it as an argument against the democratic inclusion of those who seem to exclude themselves.

Because of the ambiguities of the visibility discourse, the strong judgements on minorities are often used in order to promote a politics of fear and resentment (Nussbaum 2012, 2018). If a ban on religious symbols is not presented in a generalized way in the name of secular neutrality, it can be specified as a critique of a particular tradition, in most cases Islam. The ethnocentrism of a dominant culture identifies a disturbing religion and uses Islamophobia as an instrument of propaganda. The more helpful approach would be to make the difference between a legitimate critique of any religion without taboos and an ostracism that makes dialogue and reasonable critique impossible. It is more likely that bans and verbal aggressions foster radicalization. 


\section{Back to Rationality? Some Perspectives for Further Discussion}

It is hard to say how to calm such a poisoned debate. Robust liberal societies should not be afraid of a more agonistic style of political clashes (Mouffe 2013). However, they are not sure to have the resources to cope with the rise of new radical political and religious movements. It is part of the self-image of modern societies to be proud of having overcome extremist and inhuman attitudes like racism. We must admit that this is not true when the ethnicization of allegedly religious conflicts has racist connotations (Kamaloni 2019). The storytelling of the modernist narrative (Becker 2007) is in desperate need of new impulses if it does not want to get stuck in the contrast of moralizing liberal discourses on one side and illiberal hate speech on the other side. It does not really help to brand the political opponent as irrational and to persist with one's own position as the only rationally acceptable choice. Such a strategy would underestimate the pitfalls of reason and the impact of emotions on the publicly performed political competition.

Contemporary societies seem to have lost a certain degree of creativity, which is necessary if we have to stage pluralism and to combat the forces of social division and polarization. The diversity of lifestyles and beliefs is not just an abstract concept; it is a real-life task for which everybody is called to leave the comfort zone of cherished habits and convictions. Sennett (1977) has written extensively on the importance of urban life for the confrontation between positions presenting incompatible goals. His diagnosis in the book from the late 1970s is still relevant today. Sennett regrets the retreat of individuals from public engagement when they prefer to cultivate personal ideals of authenticity in the cozy bubble of their private lives. This can be seen as a legitimate option when it does not block the road to a visible display of publicly interesting lifestyles, which should be known in order to be discussed, respected, and criticized. Dissident voices must be heard and irritating manifestations must be seen as long as they try to argue on the ground of democracy and the state of law. Populism cannot and should not be silenced or made invisible. Such a ban would only confirm the suspicion that an established order is no longer willing to listen to justified and understandable concerns of a growing number of citizens. Those who make a strong case for the fair access of all citizens to public visibility must consistently be open to the irritating effects of political movements trying to exclude some religions from recognition. The most probable meeting places of a variety of individuals and groups are in cities all over the world. That is why cities are important laboratories for experiences of diversity and tolerance in disintegrated societies (Dassetto 2013; Salzbrunn 2019) and starting points for experiments of inclusion. Cities are the places where bell towers and minarets, churches, and mosques can be seen as integral parts of an open and esthetically designed urban landscape that facilitates encounters of people coming from different traditions.

The visibility of conflicting values makes the experience of democratic participation vivid and attractive. If personal options are systematically hidden from the public view, they risk to be considered as obscure and potentially dangerous. In the long run, the enigmatic nature of such opinions and beliefs triggers more hostility than any open confrontation under the rules of fairness. The analysis of the visibility of religion is an appropriate way of deconstructing populist conspiracy theories and of inviting religious people to accept their own and not minor part of responsibility in the perception of their public image.

Funding: This research received no external funding.

Conflicts of Interest: The author declares no conflict of interest.

\section{References}

Althoff, Andrea. 2018. Right-wing populism and religion in Germany: Conservative Christians and the Alternative for Germany (AfD). Zeitschrift für Religion, Gesellschaft und Politik 2: 335-63. [CrossRef]

Assemblée nationale du Québec. 2013. Bill 60, Charter Affirming the Values of State Secularism and Religious Neutrality and of Equality between Women and Men, and Providing a Framework for Accommodation Requests. Available online: http://www.assnat.qc.ca/en/travaux-parlementaires/projets-loi/projet-loi-60-40-1. html?appelant=MC (accessed on 27 June 2020). 
Battistella, Graziano. 2017. From Invisibility to Recognition: Reflections on the Conditions of Migrants in Our Society. Center for Migration Studies (Keynote address delivered at the Fifth Exodus Conference in Singapoure). Available online: https://cmsny.org/publications/invisibility-recognition/ (accessed on 27 June 2020).

Beaman, Lori G. 2014. Between the Public and the Private. Governing Religious Expression. In Religion in the Public Sphere. Canadian Case Studies. Edited by Solange Lefebvre and Lori G. Beaman. Toronto: University of Toronto Press, pp. 44-65.

Becker, Howard S. 2007. Telling about Society. Chicago: The University of Chicago Press.

Bochinger, Christoph, Martin Engelbrecht, and Winfried Gebhardt. 2009. Die Unsichtbare Religion in der Sichtbaren Religion-Formen Spiritueller Orientierung in der Religiösen Gegenwartskultur. Stuttgart: Kohlhammer.

Bonikowski, Bart. 2016. Three Lessons of Contemporary Populism in Europe and the United States. The Brown Journal of World Affairs 23: 9-24.

Bouchard, Gérard, and Charles Taylor, eds. 2008. Building the Future. A Time for Reconciliation. Abridged Report. Québec: Gouvernement du Québec. Available online: http://numerique.banq.qc.ca/patrimoine/details/52327/ 66286 (accessed on 27 June 2020).

Carens, Joseph H. 2013. The Ethics of Immigration. Oxford and New York: Oxford University Press.

Casanova, José. 1994. Public Religions in the Modern World. Chicago: The University of Chicago Press.

Dassetto, Felice. 2013. L'Iris et le Croissant. Bruxelles et l'Islam au défi de la co-Inclusion. Louvain-la-Neuve: Presses Universitaires de Louvain.

DeHanas, Daniel Nilsson, and Marat Shterin, eds. 2019. Religion and the Rise of Populism. London and New York: Routledge.

Doganyilmaz Duman, Didem. 2018. Islam's increased visibility in the European public sphere. A real crisis? Scripta Instituti Donneriani Aboensis 28: 68-91. [CrossRef]

Göle, Nilüfer. 2011. The public visibility of Islam and European politics of resentment: The minarets-mosques debate. Philosophy and Social Criticism 37: 383-92. [CrossRef]

Gonzalez, Philippe. 2015. Montrer les minarets pour imposer une Suisse "chrétienne". Les sources évangéliques d'une initiative populaire. In Quel âge Post-Séculier? Religions, Démocraties, Sciences. Edited by Joan Stavo-Debauge, Philippe Gonzalez and Roberto Frega. Paris: Éditions de l'EHESS, pp. 249-84.

Hjelm, Titus, ed. 2015. Is God Back? Reconsidering the New Visibility of Religion. London: Bloomsburg Academic.

Jonker, Gerdien, and Valérie Amiraux, eds. 2006. Politics of Visibility. Young Muslims in European Public Spaces. Bielefeld: Transcript.

Kamaloni, Sunshine. 2019. Understanding Racism in a Post-Racist World. Visible Invisibilities. Cham: Palgrave Macmillan. Knoblauch, Hubert. 2003. Europe and Invisible Religion. Social Compass 50: 267-74. [CrossRef]

Könemann, Judith, and Saskia Wendel, eds. 2016. Religion, Öffentlichkeit, Moderne. Transdisziplinäre Perspektiven. Bielefeld: Transcript.

Lesch, Walter, ed. 2017. Christentum und Populismus. Klare Fronten? Freiburg: Herder.

Luckmann, Thomas. 1967. The Invisible Religion. The Problem of Religion in Modern Society. New York: Macmillan.

Marzouki, Nadia, Duncan McDonnell, and Olivier Roy, eds. 2016. Saving the People. How Populists Hijack Religion. New York: Oxford University Press.

Mendieta, Eduardo, and Jonathan VanAntwerpen, eds. 2011. The Power of Religion in the Public Sphere. New York: Columbia University Press.

Mouffe, Chantal. 2013. Agonistics. Thinking the World Politically. London and New York: Verso.

Mudde, Cas, and Cristóbal Rovira Kaltwasser. 2017. Populism. A Very Short Introduction. Oxford: Oxford University Press.

Nilsson, Per-Erik. 2018. French Populism and Discourses on Secularism. London: Bloomsbury Academic.

Nussbaum, Martha C. 2012. The New Religious Intolerance. Overcoming the Politics of Fear in an Anxious Age. Cambridge and London: The Belknap Press of Harvard University Press.

Nussbaum, Martha C. 2018. The Monarchy of Fear. A Philosopher Looks at our Political Crisis. Oxford: Oxford University Press.

Salzbrunn, Monika, ed. 2019. L'islam (in)visible en ville. Appartenances et Engagements dans l'Espace Urbain. Geneva: Labor et Fides.

Scott, Joan W. 2007. The Politics of the Veil. Princeton and Oxford: Princeton University Press.

Sennett, Richard. 1977. The Fall of Public Man. New York: Alfred A. Knopf. 
Urbinati, Nadia. 2013. The Populist Phenomenon. Raisons Politiques 3: 137-54. [CrossRef]

Ward, Graham, and Michael Hoelzl, eds. 2008. The New Visibility of Religion. Studies in Religion and Cultural Hermeneutics. London and New York: Continuum.

Wellman, David Joseph. 2019. Trump, the Cross, and the Lynching Tree. White Christian Nationalism and the Future of American Political Identity. In Gender-Nation-Religion. Ein Internationaler Vergleich von Akteursstrategien und Diskursverflechtungen. Edited by Maren Behrensen, Marianne Heimbach-Steins and Linda E. Hennig. Frankfurt and New York: Campus, pp. 81-100.

Zúquete, Jose Pedro. 2017. Populism and Religion. In The Oxford Handbook of Populism. Edited by Cristóbal Rovira Kaltwasser, Paul Taggart, Paulina Ochoa Espejo and Pierre Ostiguy. Oxford: Oxford University Press, pp. 445-66.

(C) 2020 by the author. Licensee MDPI, Basel, Switzerland. This article is an open access article distributed under the terms and conditions of the Creative Commons Attribution (CC BY) license (http://creativecommons.org/licenses/by/4.0/). 